\title{
PEMANFAATAN MAKANAN OLEH UDANG GALAH (Macrobranchium rosenbergii) DAN INTERAKSINYA DENGAN JENIS IKAN DI WADUK DARMA
}

\author{
Didik Wahju Hendro Tjahjo") dan Sri Endah Purnamaningtyas")
}

\begin{abstract}
ABSTRAK
Tujuan penelitian ini adalah untuk mengevaluasi penebaran udang galah (Macrobranchium rosenbergii) di Waduk Darma ditinjau dari pemanfaatan makanan dan interaksi udang galah dengan jenis ikan yang ada. Penebaran udang galah dilakukan 3 kali yaitu bulan April, Agustus, dan September. Pengamatan dilakukan satu bulan sekali dari bulan Maret 2002 sampai Januari 2003. Analisis pemanfaatan makanan dan interaksi antar jenis ikan meliputi analisis kebiasaan makanan dan interaksi antara udang galah dengan jenis ikan dominan baik dalam pemanfaatan makanan maupun ruang. Hasil penelitian ini dapat disimpulkan bahwa udang galah mempunyai makanan utama tumbuhan. Hal tersebut berarti penebaran udang galah mampu memanfaatkan potensi makanan (tumbuhan) yang belum termanfaatkan secara optimal sehingga mempunyai peluang terjadinya kompetisi yang rendah, baik makanan maupun ruang untuk mengisi relung ekologi yang kosong.
\end{abstract}

ABSTRACT: Food resources utilization by giant freshwater prawn (Macrobranchium rosenbergii) and their interaction with fish species in Darma Reservoir. By: Didik Wahju Hendro Tjahjo") and Sri Endah Purnamaningtyas"

\begin{abstract}
The aim of the study was to evaluate the status of giant freshwater prawn (Macrobranchium rosenbergii) stocked in Darma Reservoir intern of food utilization and fish species interaction. Giant freshwater prawn were stocked three times, started April, August, and September 2002. Observations were conducted every month since March 2002 to January 2003. Evaluations were done using the analysis of food habit and dominant fish species interaction either with habitat or food. The results of the study showed that the primary food of giant freshwater prawn was plant materials. Thus, the prawn has able to used food potential which is not optimally used. The prawn also indicate low competition, either for habitat or food with the dominant fish species. It could be concluded that giant freshwater prawn stocked in Darma Reservoir was able to utilize the empty ecological niche.
\end{abstract}

KEYWORDS: Darma Reservoir, food utilization, giant prawn, interaction, stocking

\section{PENDAHULUAN}

Waduk Darma terletak $14 \mathrm{~km}$ di sebelah barat Kota Kuningan, dibangun untuk keperluan irigasi dan mulai digenangi tahun 1948. Luas maksimum waduk mencapai 410 ha dan termasuk perairan yang subur. Hasil tangkapan ikan jauh dibawah potensi sumber daya ikan yang ada. Kesenjangan antara potensi dan hasil tangkapan tersebut disebabkan dominasi yang terlalu kuat dari ikan nila sehingga menyebabkan produksi ikan rendah, dan relung ekologi belum termanfaatkan seluruhnya (Tjahjo et. al., 2004). Potensi sumber daya pakan yang besar dan belum banyak dimanfaatkan oleh komunitas ikan adalah makrofita (Tjahjo et. al., 2001). Jenis ikan yang mampu memanfaatkan makrofita adalah tawes dan udang galah (Samuel et. al., 1991; Kurup \& Hariskrishman, 2000).

Hasil evaluasi penebaran udang galah di Waduk Darma, Jawa Barat berdasarkan kualitas air dan potensi sumber daya perikanan (Tjahjo et. al., 2004) menunjukkan bahwa kualitas perairan Waduk Darma, baik secara fisik, kimia, dan biologi, mendukung kehidupan dan pertumbuhan udang galah, serta total potensi produksi ikan dan udang yang berkisar antara $113,47-306,57$ ton per tahun dan minimal mampu mendukung biomass udang sebesar 8,67 ton per tahun atau $723 \mathrm{~kg}$ per bulan.

Penebaran udang galah dilakukan 3 kali yaitu bulan April, Agustus, dan September 2002. Benih udang tersebut sebelum ditebar, diadaptasikan terlebih dahulu selama 1-3 bulan (Tabel 1) dengan padat tebar 650 ekor $\mathrm{m}^{2}$. Adaptasi benih tersebut dilakukan dalam KJA (keramba jaring apung) dengan ukuran kantong $2 \times 2 \times 1,5 \mathrm{~m}$ dan ukuran mata jaring $0,1 \mathrm{~cm}$. di Waduk Darma dan diberi pakan komersial sebanyak $3 \%$ dari berat tubuh. Selanjutnya, setelah benih tersebut selesai diadaptasi, benih udang ditebarkan dengan "Sistim Tricker" dan jumlah benih udang galah yang ditebar di Waduk Darma pada bulan April, September, dan Agustus secara berturut-turut adalah 4.135 ekor, 16.309 ekor dan 675 ekor.

Penelitian ini berusaha menjawab 2 pertanyaan, yaitu "Apakah udang galah yang ditebar tersebut mampu memanfaatkan potensi makanan yang belum dimanfaatkan (makrofita)?" dan "Apakah udang tersebut mengisi relung ekologi yang kosong?". Oleh karena itu, tujuan penelitian ini adalah untuk mengevaluasi keberhasilan penebaran udang galah di Waduk Darma ditinjau dari pemanfaatan makanan dan interaksi udang galah dengan jenis ikan yang ada.

\footnotetext{
-) Peneliti pada Loka Riset Pemacuan Stok Ikan, Jatiluhur
} 
Tabel 1. Data proses adaptasi sebelum penebaran udeng galah (Macrobrachium rosenbergii) Table 1. Data of adaptation process of giant freshwater prawn (Macrobranchium rosenbergii)

\begin{tabular}{|c|c|c|c|c|c|c|c|c|}
\hline \multirow[b]{2}{*}{ No. } & \multicolumn{2}{|c|}{$\begin{array}{l}\text { Waktu Adaptasi } \\
\text { Adaptation time }\end{array}$} & \multirow{2}{*}{$\begin{array}{c}\text { Umur } \\
\text { Awal } \\
\text { (bulan) } \\
\text { Initial } \\
\text { Age } \\
\text { (month) }\end{array}$} & \multirow{2}{*}{$\begin{array}{c}\text { Lama } \\
\text { Adaptäsi } \\
\text { (bulan) } \\
\text { Adaptation } \\
\text { Time } \\
\text { (month) }\end{array}$} & \multicolumn{2}{|c|}{$\begin{array}{c}\text { Awal Adaptasi } \\
\text { Initial of Adaptation }\end{array}$} & \multicolumn{2}{|c|}{$\begin{array}{l}\text { Akhir Adaptasi } \\
\text { End of Adaptation }\end{array}$} \\
\hline & $\begin{array}{l}\text { Mulai } \\
\text { Initial }\end{array}$ & $\begin{array}{l}\text { Akhir } \\
\text { End }\end{array}$ & & & $\begin{array}{l}\text { Panjang } \\
\text { (cm) } \\
\text { Length } \\
\text { (cm) }\end{array}$ & $\begin{array}{c}\text { Jumlah } \\
\text { (ekor) } \\
\text { Numbers } \\
\text { (ind.) }\end{array}$ & $\begin{array}{l}\text { Panjang } \\
\text { (cm) } \\
\text { Length } \\
\text { (cm) }\end{array}$ & $\begin{array}{c}\text { Jumlah } \\
\text { (ekor) } \\
\text { Numbers } \\
\text { (ind.) }\end{array}$ \\
\hline 1 & $\begin{array}{l}\text { Maret } \\
\text { March }\end{array}$ & $\begin{array}{l}\text { April } \\
\text { April }\end{array}$ & 2 & 1 & 2,7 & 10.100 & 3,2 & 4.135 \\
\hline 2 & $\begin{array}{l}\text { Juni } \\
\text { June }\end{array}$ & $\begin{array}{l}\text { September } \\
\text { September }\end{array}$ & 1 & 3 & 1,3 & 40.425 & 3,1 & 16.309 \\
\hline 3 & $\begin{array}{l}\text { Juli } \\
\text { July }\end{array}$ & $\begin{array}{l}\text { Agustus } \\
\text { August }\end{array}$ & 3 & 1 & 5,6 & 1.000 & 5,8 & 675 \\
\hline
\end{tabular}

\section{BAHAN DAN METODE}

\section{Pengumpulan Data}

Kimmel \& George pada tahun 1984 dalam Ryding dan Rast (1989) menyatakan bahwa karakteristik perairan waduk secara umum dapat dibagi menjadi 3 bagian, yaitu hulu, tengah, dan hilir (daerah dekat dam). Pengambilan contoh uciang dan ikan dilakukan di 4 stasiun pengamatan dengan mempertimbangkan karakteristik perairan waduk secara umum tersebut. Lokasi stasiun pengamatan adalah sebagai berikut Stasiun 1 merupakan daerah hulu perairan waduk di mana tempat bermuara Sungai Cibunut, Cilama, Cikelapa, dan Cikupa; Stasiun 2 merupakan daerah genangan utama Waduk Darma; Stasiun 3 merupakan daerah hulu perairan waduk di mana tepat bermuara Sungai Cilandak dan Stasiun 4 daerah dekat dam (Lampiran 1).

Pengamatan dilakukan 1 bulan sekali dari bulan Maret 2002-Maret 2003. Setiap kali pengamatan dilakukan pengambilan contoh udang dan ikan (saat air surut terendah) sampai di 4 stasiun pengamatan. Pengambilan contoh dilakukan dengan menggunakan jaring insang dan jala lempar. Ukuran mata jaring insang adalah $1,1 \frac{1}{2}, 2,2 \frac{1}{2}, 3,3 \frac{1}{2}$, dan 4 inci dengan panjang dan lebar jaring masing-masing adalah $35 \mathrm{~m}$ dan $2,5 \mathrm{~m}$. Ukuran mata jaring jala lempar adalah 1 inci bagian bawah dan $1 \frac{1}{2}$ inci di bagian atas dengan diameter jaring $6 \mathrm{~m}$. Ikan dan udang yang tertangkap diukur panjang-beratnya dan diambil lambungnya, lalu diawetkan dalam formalin $5 \%$, selanjutnya dianalisis kebiasaan pakannya di laboratorium Loka Riset Pemacuan Stok Ikan Jatiluhur.

\section{Analisis Data}

Analisis pemanfaatan makanan dan interaksi antar jenis ikan meliputi analisis kebiasaan makanan dan interaksi antara udang galah dengan jenis ikan dominan baik dalam pemanfaatan makanan maupun ruang. Analisis kebiasaan pakan dengan menggunakan metode Indeks Preponderans
(Natarajan \& Jhingran dalam Effendie, 1979), dengan bentuk rumus sebagai berikut:

$$
I_{i}=\frac{O_{i} \times V_{i}}{\sum\left(O_{i} \times V_{i}\right)}
$$

di mana:

$I_{i}=$ Indeks Preponderans kelompok pakan ke-i,

$\mathrm{O}_{i}=$ persentase kejadian pakan ke-i,

$V_{i}=$ persentase volume pakan ke- $i$.

Interaksi antara udang galah dengan jenis ikan dominan terhadap ruang dan pakan dianalisis dengan 2 tahapan. Tahap pertama, menggunakan analisis pengelompokkan terhadap distribusi horisontal dan pakan yang dimanfaatkan oleh ikan dan udang dengan menggunakan jarak Euclidiean (Legendre \& Legendre, 1983; Ludwig \& Reynolds, 1988; Sokal \& Rohlf, 1995), dengan rumus sebagai berikut:

$$
D_{1}\left(x_{1}, x_{2}\right)=\sqrt{\sum_{i=1}^{n}\left(y_{i 1}-y_{i 2}\right)^{2}}
$$

di mana:

$\mathrm{D}=$ jarak Euclidiean,

$x=$ jenis ikan atau kelompok pakan,

y = peubah yang diamati,

I = bervariasi dari 1 sampai $n$ yang menunjukkan indeks peubah,

$\mathrm{n}$ = banyaknya peubah yang diamati.

Tahap kedua, dilakukan analisis secara bersamaan dengan menggunakan analisis nodul, lalu dihitung dengan Indeks Constancy $\left(C_{i j}\right)$ dan Indeks Fidelity $\left(F_{i j}\right)$ (Boesch dalam Murphy \& Edwards, 1982) dengan rumus:

$$
C_{i j}=\frac{a_{i j}}{n_{i} \times n_{j}} \quad F_{i j}=\frac{C_{i j}^{\prime}}{\sum \frac{a_{i j}}{n_{i} \times \sum n_{j}}}
$$

di mana:

$$
\begin{aligned}
a_{i j}= & \text { jumlah aktual anggota spesies } \mathrm{i} \text { pada } \\
& \text { kelompok pakan ke } \mathrm{j}, \\
n_{\mathrm{i}} \text { dan } n_{j}= & \begin{array}{l}
\text { jumlah spesies kelompok ikan ke } \mathrm{i} \text { dan } \\
\text { kelompok pakan ke } \mathrm{j} .
\end{array}
\end{aligned}
$$




\section{HASIL DAN PEMBAHASAN}

Pertumbuhan bobot udang galah di Waduk Darma banyak dipengaruhi faktor lingkungan bila dibandingkan pertumbuhan panjang. Faktor lingkungan yang penting adalah makanan, baik kualitas maupun kuantitas, sehingga ada hubungan atau korelasi yang erat antara makanan dan bobot terhadap laju pertumbuhan.

\section{Kebiasaan Makanan}

Kualitas makanan merupakan salah satu faktor yang menentukan pertumbuhan udang, di mana kualitas makanan yang dikonsumsi udang galah dapat diketahui lewat kebiasaan makanannya. Ling \& Merican dalam Spotts (2001) menyatakan bahwa udang galah yang merupakan hewan omnivora penghuni dasar yang makanan alaminya berupa cacing, siput, kerang, ikan, potongan padi, gandum, buncis, biji-bijian, tanaman air, dan buah-buahan. Menurut Wynne (2002) Udang Galah termasuk pemakan organisme dasar dan pemakan bangkai yang omnivora. D'Abramo \& Brunson (1996) menyatakan makanan udang galah adalah potongan hewan dan tumbuhan, larva dan serangga dewasa, alga, moluska, cacing, ikan dan kotoran ikan, serta udang ini cenderung bersifat kanibal pada kondisi kepadatan tinggi dan makanan yang tersedia terbatas. Samuel et. al., (1991) menyatakan bahwa udang galah di Sungai Lempuing makanan alami utamanya adalah detritus. Di Waduk Darma, udang galah berukuran besar memanfaatkan serasah dan organisme (hewan) sebagai makanannya (Satria, 2001). Di Danau Vembanad, India, udang galah mengkonsumsi biji-bijian padi sisa panen dan potongan tumbuhan yang mulai membusuk, dan persawahan di daerah draw-down merupakan daerah yang penting dalam mendukung pertumbuhan udang tersebut walaupun tidak untuk waktu yang lama (Kurup \& Hariskrishman, 2000). Demikian juga, untuk Waduk Darma yang mempunyai daerah draw-down yang luas $(18,1-43,1 \%$ luas maksimum) yang mempunyai potensi makanan tinggi bagi udang galah, jika daerah tersebut ditumbuhi oleh tumbuhan.

Hasil penelitian kebiasaan makanan udang galah dengan ukuran panjang total berkisar antara 5,2-23,0 $\mathrm{cm}$ tertera dalam Tabel 2. Batasan makanan utama, pelengkap dan tambahan adalah sebagai berikut makanan utama adalah kelompok makanan yang mempunyai nilai indeks preponderan lebih besar dari $25 \%$, makanan pelengkap merupakan kelompok makanan yang mempunyai nilai indeks preponderan berkisar antara $5-25 \%$, dan makanan tambahan merupakan kelompok makanan yang mempunyai nilai indeks preponderan kurang dari $5 \%$. Secara umum kebiasaan makanan udang galah di Waduk Darma menunjukkan bahwa makanan utamanya adalah tumbuhan, sedangkan serangga dan moluska sebagai makanan pelengkap. Pada kondisi muka air waduk semakin surut (Tinggi Muka Air atau TMA semakin rendah) udang tersebut semakin banyak mengkonsumsi kelompok makanan moluska, serangga, dan udang. Sebaliknya pada kondisi permuka air waduk semakin luas, udang tersebut semakin banyak mengkonsumsi tumbuhan. Hal tersebut disebabkan pada saat kondisi air menjeiang surut terendah, kesediaan tumbuhan sebagai makanannya sangat terbatas, sebaliknya pada saat TMA naik, air tersebut akan mengenangi tumbuhan yang tumbuh di daerah draw-down (pasang-surut), sehingga kesediaan makanan udang galah berupa tumbuhan meningkat. Berdasarkan kebiasaan dan pakan udang galah di Waduk Darma menunjukkan bahwa udang tersebut mampu memanfaatkan potensi makanan (tumbuhan) secara optimal.

Tabel 2. Kebiasaan makanan udang galah (5) dan Tinggi Muka Air (m) di Waduk Darma untuk setiap waktu pengamatan

Table 2. Food habits of GiantFreshwaterPrawn (\%) and Water Level $(m)$ each observation time in Darma Reservoir

\begin{tabular}{|c|c|c|c|c|c|c|c|}
\hline \multirow{2}{*}{$\begin{array}{l}\text { Peubah/ } \\
\text { variable }\end{array}$} & \multicolumn{7}{|c|}{$\begin{array}{l}\text { Indeks Preponderan (\%) } \\
\text { Index of Preponderance (\%) }\end{array}$} \\
\hline & $\begin{array}{l}\text { Agu. } \\
\text { Aug. }\end{array}$ & $\begin{array}{l}\text { Sep. } \\
\text { Sept. }\end{array}$ & $\begin{array}{l}\text { Okt. } \\
\text { Oct. }\end{array}$ & $\begin{array}{l}\text { Nop. } \\
\text { Nov. }\end{array}$ & $\begin{array}{l}\text { Des. } \\
\text { Dec. }\end{array}$ & $\begin{array}{l}\text { Jan. } \\
\text { Jan. }\end{array}$ & $\begin{array}{l}\text { Mar. } \\
\text { Mar. }\end{array}$ \\
\hline $\begin{array}{l}\text { Tumbuhan } \\
\text { Vegetation }\end{array}$ & 96,20 & 58,93 & 47,20 & 0 & 25,44 & 20,00 & 96,12 \\
\hline $\begin{array}{l}\text { Detritus } \\
\text { Detritus }\end{array}$ & & & 4,00 & 8,69 & & 20,00 & \\
\hline $\begin{array}{l}\text { Siput } \\
\text { Mollusca }\end{array}$ & & 8,93 & & 69,57 & 1,00 & 20,00 & 3,88 \\
\hline $\begin{array}{l}\text { Serangga } \\
\text { Insect }\end{array}$ & 3,80 & 32,14 & 48,80 & 21,74 & 69,58 & & \\
\hline $\begin{array}{l}\text { Udang } \\
\text { Prawn }\end{array}$ & & & & & 3,99 & 20,00 & \\
\hline $\begin{array}{l}\text { Ikan } \\
\text { Fish }\end{array}$ & & & & & & 20,00 & \\
\hline $\begin{array}{l}\text { Tinggi Muka Air (m) } \\
\text { Water Levels }(m)\end{array}$ & 710,5 & 708,6 & 706,0 & 703,7 & 704,1 & 705,2 & 709,2 \\
\hline
\end{tabular}




\section{Interaksi antar Jenis Ikan}

Interaksi antar jenis ikan terjadi jika suatu jenis ikan mempunyai preferensi terhadap makanan dan atau habitat yang sama dengan jenis ikan lainnya. Jika jenis ikan tersebut mempunyai preferensi habitat dan makanan yang sama dengan jenis ikan lainnya, maka ikan tersebut mempunyai peluang kompetisi yang tinggi. Jika hanya mempunyai kesamaan dalam memanfaatkan makanan atau habitat, maka bersifat interaksi tersebut komplementaritas.

Analisis interaksi antar jenis ikan melalui 2 tahapan. Pertama, adalah mengelompokkan makanan dan ikan. Pengelompokkan makanan berdasarkan tingkat pemanfaatan oleh ikan yang ada, sedangkan pengelompokan ikan berdasarkan distribusi horisontalnya. Kedua, hasil analisis tersebut dianalisis secara bersama-sama dengan menggunakan analisis nodul, dan akhirnya dihitung dengan indeks "Constancy" dan "Fidelity".

Berdasarkan pola pemanfaatkan makanan oleh jenis ikan dan udang yang ada, makanan tersebut dapat dikelompokkan menjadi 4 kelompok, yaitu (1) kelompok 1 yang hanya terdiri dari fitoplakton, (2) kelompok 2 terdiri dari tumbuhan, detritus, dan zooplankton, (3) kelompok 3 terdiri dari larva serangga, moluska, udang, dan serangga, dan (4) kelompok 4 hanya terdiri dari ikan (Gambar 1).

Kelompok makanan 1 berupa fitoplankton banyak dimanfaatkan oleh ikan nila (Oreochromis nilotica) dan nilem (Osteochilus hasselti) di mana fitoplankton ini dikonsumsi sekitar $63-85 \%$ dari volume makanan kedua jenis ikan tersebut (Gambar 2). Kelompok makanan 2 yang terdiri dari (a) tumbuhan dikonsumsi oleh udang galah, udang lokal (Macrobrachium hildebrandti), dan beunteur (Puntius binotatus), (b) detritus dikonsumsi oleh pepetek dan nila, dan (c) zooplankton dikonsumsi hanya oleh pepetek (Parambassis punctulata). Kelompok makanan 3 yang terdiri atas larva serangga, moluska, dan serangga di mana serangga banyak dikonsumsi oleh goldsom (Aeqvidens goldsoum) dan slebra (Tilapia thollani), sedangkan jenis makanan lainnya (larva serangga dan moluska) kurang dimanfaatkan oleh jenis ikan dan udang yang ada. Kelompok makanan 4 yang berupa ikan, makanan dalam kelompok ini dimanfaatkan oleh jenis ikan predator, seperti goldsom, monogoi (Cyrtocara rostrata) dan gabus (Channa striata).

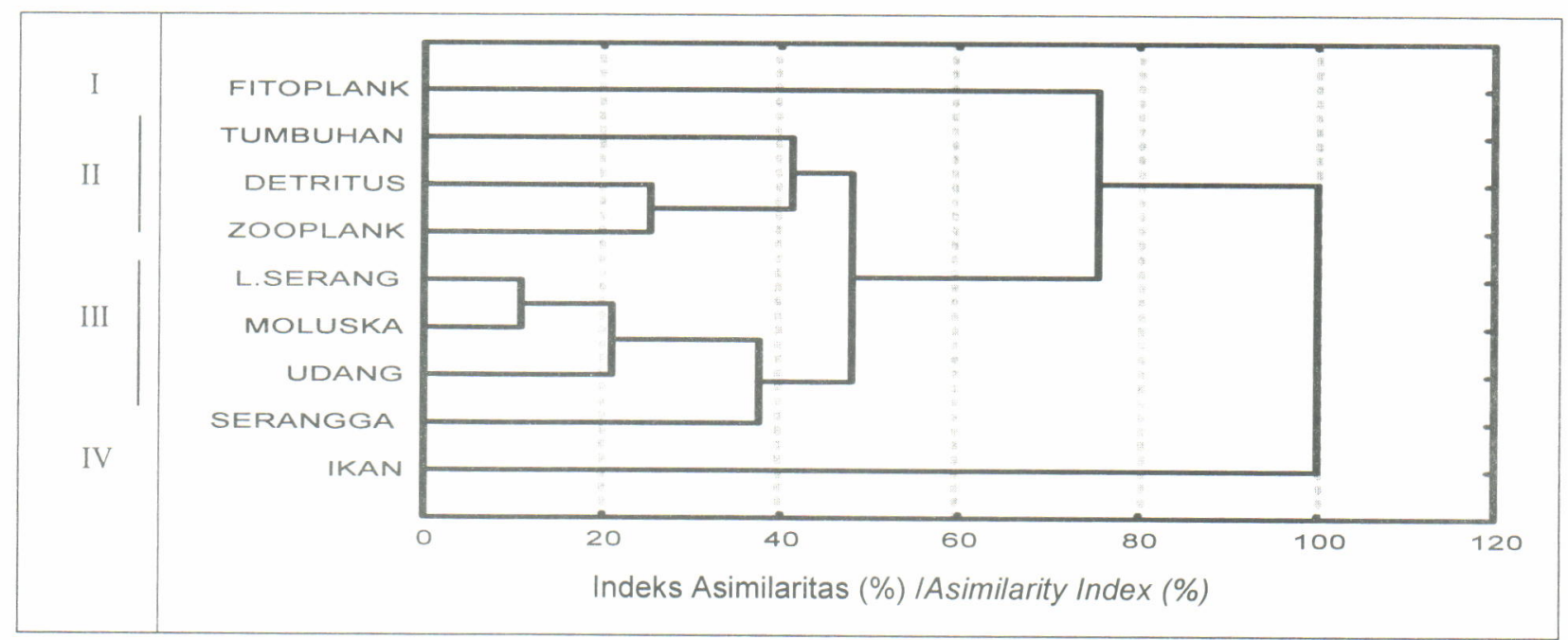

Gambar 1

Pengelompokkan makanan berdasarkan tingkat pemanfaatan oleh ikan dan udang galah (I, II, III, dan IV = kelompok pakan I, II, III, dan IV, FITOPLANK = fitoplankton, ZOOPLANK = zooplankton, L. SERANG = larva serangga).

Figure 1. Clustering of food resources based on their utilization of the fish and Prawn (I, II, III and IV = food groups, FITOPLANK = phytoplankton, TUMBUHAN = plant material, DETRITUS = detritus, ZOOPLANK = zooplankton, L.SERANG = insect larva, MOLUSKA = mollusk, UDANG = prawn, SERANGGA = insect, $I K A N=$ fish)

Berdasarkan distribusi horisontal dari jenis ikan dan udang yang ada, jenis ikan dan udang tersebut dapat digolongkan menjadi 4 kelompok, yaitu (1) kelompok 1 yang terdiri dari ikan pepetek, nila, slebra, dan udang lokal, kelompok 2 terdiri dari ikan beunteur, kelompok 3 terdiri dari nilem dan gabus, dan kelompok 4 terdiri dari goldsom, monogoi, dan udang galah (Gambar 3). Kelompok ikan I yang terdiri dari pepetek, slebra, nila, dan udang lokal, merupakan kelompok jenis ikan yang mempunyai sebaran yang luas di Waduk Darma, sedangkan kelompok ikan 3 yang terdiri dari nilem dan gabus merupakan 


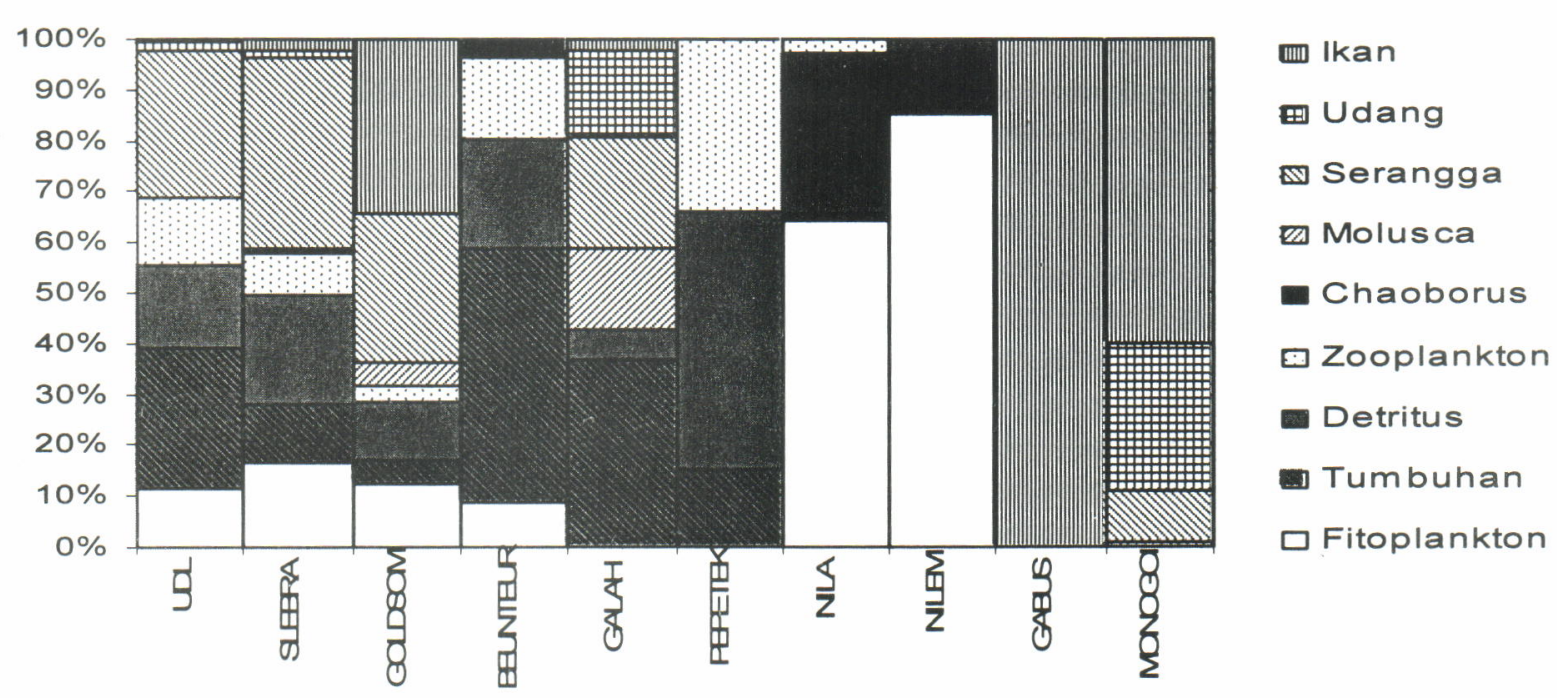

Gambar 2. Kebiasaan makanan jenis ikan dan udang di Waduk Darma (UDL = udang lokal dan GALAH = udang galah).

Figure 2. Food habit of fish species and prawn in Darma Reservoir (UDL = local prawn and GALAH = giant freshwater prawn).

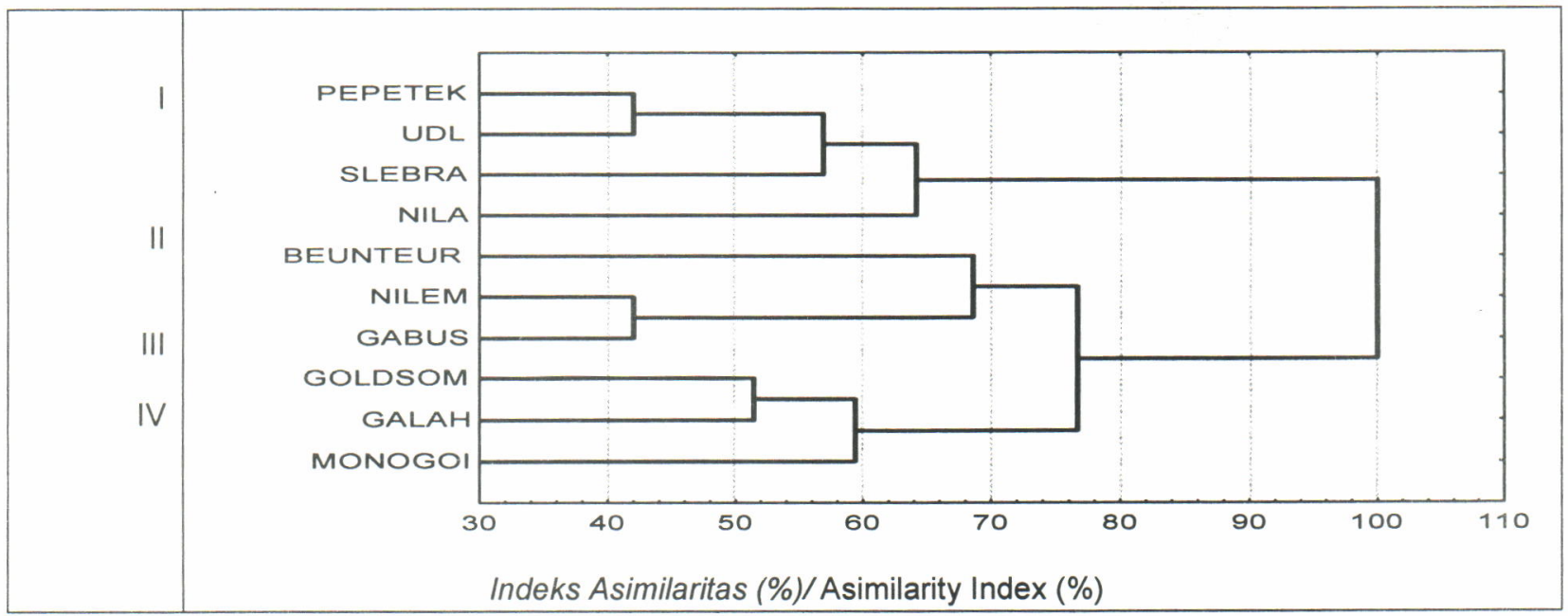

Gambar 3. $\quad$ Pengelompokkan jenis ikan berdasarkan distribusi horisontalnya di Waduk Darma (I, II, III, dan IV = kelompok ikan I, II, III, dan IV; UDL = udang lokal; GALAH = udang galah).

Figure 3. Clustering of fish speciesand prawn based on horizontal distribution in DarmaReservoir ( I, II, III, and IV = fish groups I, II, III, dan IV; UDL = local prawn; GALAH = giant freshwater prawn).

kelompok jenis ikan yang mempunyai sebaran yang sangat terbatas (Gambar 4). Kelompok ikan II yang hanya terdiri dari beunteur yang dominan di daerah muara sungai Cibunut, Cilama, Cikelapa, dan Cikupa (Stasiun 1). Kelompok ikan ini lebih dominan berada di daerah genangan utama (Stasiun 2 dan 4). Berdasarkan (1) pendapat Wynne (2002) bahwa udang galah tersebut bersifat teritorial dan tidak berenang jauh dalam mencari makanan; (2) penebaran udang galah di Waduk Darma dilakukan di daerah genangan utama; (3) morfologi daerah genangan utama yang dangkal dan landai; dan (4) ditambah kegiatan budi daya ikan di keramba jaring apung (KJA) sehingga kesediaan makanan lebih banyak daripada daerah lainnya maka pola sebaran udang tersebut berada di daerah genangan utama.

Untuk mengetahui distribusi spasial dan preferensi jenis ikan terhadap kelompok makanan, maka analisis pengelompokkan makanan dan pengelompokkan jenis ikan (Gambar 1 dan 3), dibuat matrik hubungan kedua kelompok tersebut dan akhirnya dilakukan analisis nodul memakai indeks Constancy dan Fidelity (Gambar 5). 


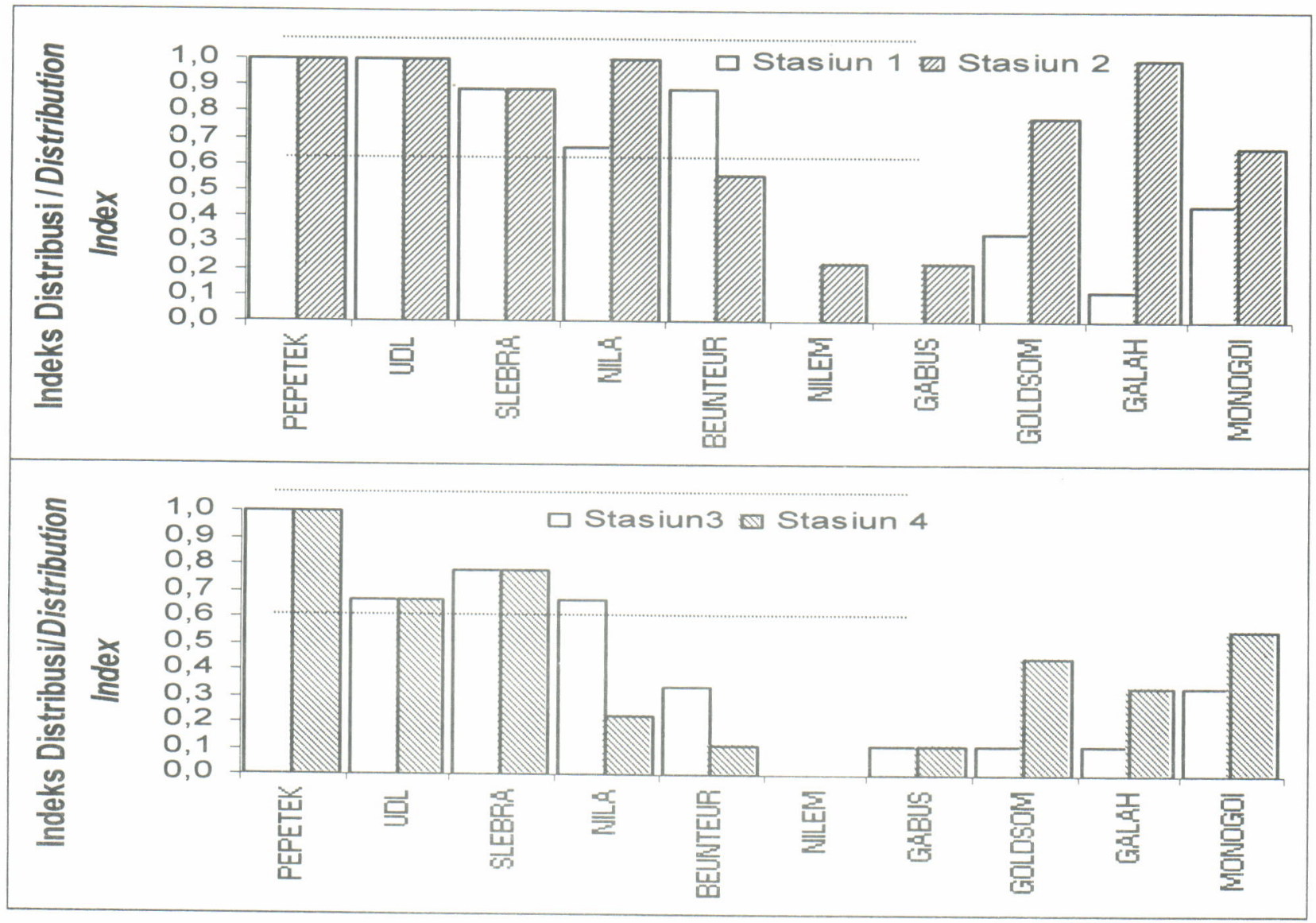

Gambar 4.

Figure 4. Fish and prawn distribution in Darma Reservoir UDL = local prawn; GALAH = giant freshwater prawn; $0=$ absence and $1=$ always present.

Kelompok ikan 1 mempunyai distribusi yang luas di Waduk Darma, dan kelompok tersebut berasosiasi cukup kuat dengan kelompok makanan 2 (tumbuhan, detritus, dan zooplankton) dan kelompok makanan 1 (fitoplankton), sehingga kelompok ikan di sini cenderung bersifat omnivora (Gambar 5a). Kelompok ikan 3 yang mempunyai distribusi yang sangat terbatas berasosiasi sangat kuat terhadap kelompok makanan 1 (fitoplankton) dan 4 (ikan), karena dalam kelompok ini terdiri dari 2 jenis ikan yang mempunyai peran yang berbeda, di mana ikan nilem bersifat herbivora spesialis fitoplankton dan ikan gabus bersifat predator spesialis ikan (piscivores). Kelompok ikan 4 yang mempunyai distribusi yang cukup luas dan berasosiasi cukup kuat terhadap kelompok makanan 4 (ikan). Hal ini, dapat dijelaskan karena kelompok ini terdiri dari 3 jenis ikan, di mana 2 jenis ikan termasuk predator yang banyak mengkonsumsi ikan dan satu jenis (udang galah) pemakan pemakan tumbuhan dan bangkai. Udang galah di Waduk Darma mempunyai peluang kompetisi yang rendah, baik untuk makanan maupun ruang.
Kelompok ikan 1 menyukai kelompok makanan 2 dan suka terhadap kelompok makanan 1 (Gambar $5 b)$, sehingga kelompok ikan 1 mempunyai potensi yang tinggi untuk berkompetisi terhadap kelompok makanan 2 dan cukup tinggi terhadap kelompok makanan 1. Kelompok ikan 4 menyukai kelompok makanan 4 dan suka terhadap kelompok makanan 3, sehingga kelompok ikan 4 mempunyai peluang untuk berkompetisi yang tinggi terhadap kelompok makanan 4 dan cukup tinggi terhadap kelompok makanan 3 .

Udang galah di Waduk Darma mempunyai peluang kompetisi yang rendah pada saat udang tersebut memanfaatkan tumbuhan sebagai makanannya, tetapi peluang kompetisi tersebut meningkat pada saat udang mengkonsumsi kelompok makanan 3 (pada saat air waduk surut). Jadi udang galah yang ditebar di Waduk Darma betul-betul mengisi relung ekologi yang kosong dan tidak berdampak negatif terhadap komunitas ikan yang ada. 


\section{FITO \\ TUMB \\ DETR \\ ZOO \\ L.SER \\ MOLUS \\ UDG \\ SER \\ IKAN}

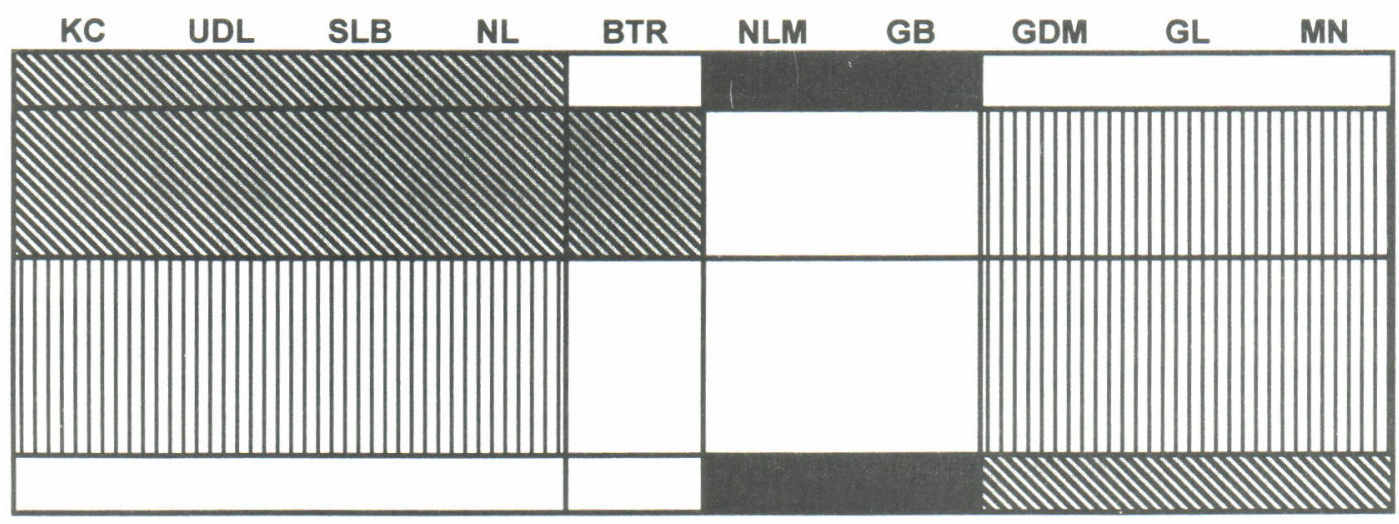

Tidak dimanfaatkan: 0-0,05

|||||||||Kurang dimanfaatkan: 0,05-0,2

NMW Cukup dimanfaatkan: 0,2-0,4

a. Indek Constancy

Banyak dimanfaatkan: 0,4-0,6

a. Indek Constancy

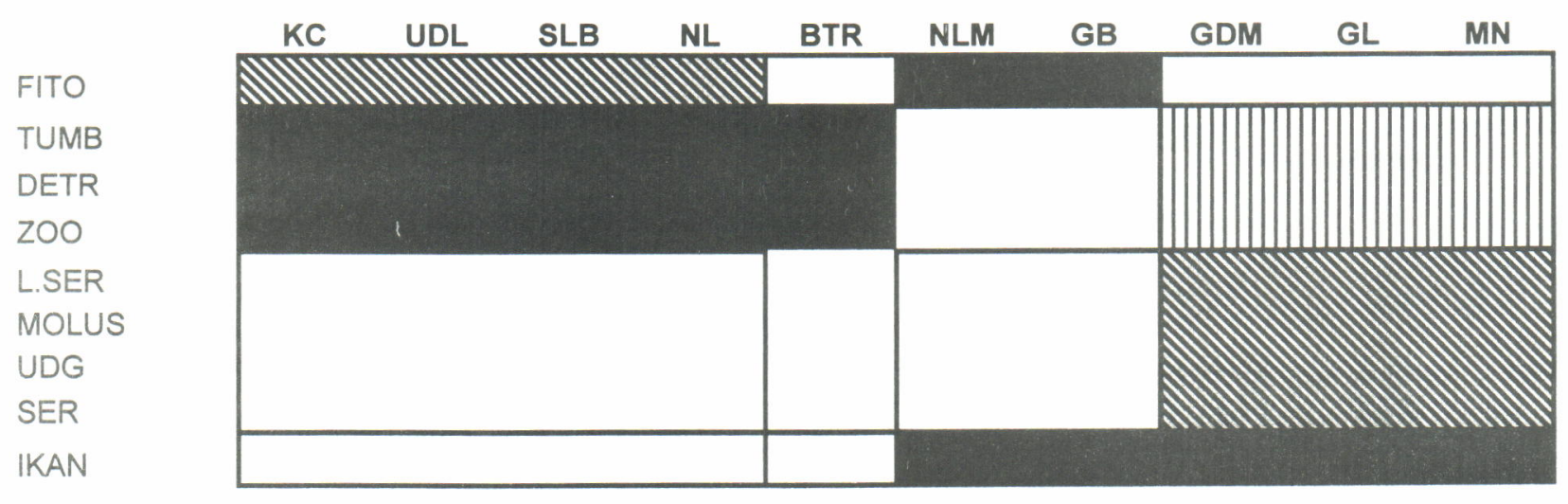

Tidak disenangi: 0-0,5

|س冋|W Kurang disenangi: 0,5-1

Disenangi: $1-2$

b. Indeks Fidelity

Sangat disenangi: $>2$

Gambar 5. Hasil analisis nodul hubungan antara kelompok jenis ikan dan kelompok makanan yang dimanfaatkan.

Keterangan: $(P P=$ pepetek; $U D L=$ udang lokal; $S L B=$ slebra; $N L=$ nila; $B T R=$ benteur; $N L M=$ nilem; $G B=$ gabus; $\mathrm{GDM}=$ goldsom; $\mathrm{GL}=$ udang galah; $\mathrm{MN}=$ monogoi; $\mathrm{FITO}=$ fitoplankton; TUMB = tumbuhan; $\mathrm{DETR}=$ detritus; $Z \mathrm{ZOO}=$ zooplankton; L.SER = larva serangga; MOLUS = moluska; UDG = udang; SER = serangga; dan IKAN = ikan)

Figure 5. Result of nodule analysis relationship between fish species groups and food utilized group. Explanation: $(P P=$ pepetek; $U D L=$ local prawn; $S L B=$ slebra; $N L=$ nile; $B T R=$ benteur; $N L M=$ nilem; $G B=$ gabus; $G D M=$ goldsom; $G L=$ giant freshwater prawn; $M N=$ monogoi; $F I T O=$ phytoplankton; $T U M B=$ macrophyta; $D E T R=$ detritus; $Z O O=$ zooplankton; $L . S E R=$ insect larva; $M O L U S=$ mollusca; UDG = prawn; $S E R=$ insect; dan IKAN = fish) 


\section{KESIMPULAN}

Berdasarkan hasil penelitian evaluasi penebaran udang galah di Waduk Darma yang ditinjau dari pemanfaatan makanan dan interaksi antar jenis ikan dapat disimpulkan bahwa:

1. Makanan utama udang galah adalah tumbuhan.

2. Penebaran udang galah mampu memanfaatkan potensi makanan (tumbuhan) yang belum termanfaatkan oleh ikan secara optimal.

3. Udang galah mempunyai peluang terjadinya kompetisi yang rendah, baik makanan maupun ruang pada saat air pasang.

4. Penebaran udang galah di Waduk Darma mampu mengisi relung ekologi yang kosong dan tidak berdampak negatif terhadap komunitas ikan yang ada.

\section{DAFTAR PUSTAKA}

D'Abramo, L. R. \& M. W. Brunson. 1996. Production of freshwater prawn in pond. Southern Regional Aquaculture Center Publiscation No.484. 6 p.

Effendie, M. I. 1979. Metoda biologi perikanan. Yayasan Dewi Sri, Bogor. 112 hal.

Kurup, B. M. \& M. Hariskrishnan. 2000. Reviving the Macrobrachium rosenbergii (de Man) fishery in Vembanad Lake, India. Naga, The ICLARM Quarterly, 23(2): p. 4-9.

Legendre, L. \& P. Legendre, 1983. Numerical ecology. Elsevier Scientific Publishing Company, New York. 419 p.

Ludwig, J. A. \& J. F. Reynolds. 1988. Statistical ecology: a primer on methods and computing. John Wiley \& Sons, New York. 335 p.

Murphy, P. M. \& R. W. Edwards. 1982. The spatial distribution of the freshwater macroinvertebrate fauna of the River Ely, in relation to pollutional discharges. Env. Poll., 29: 111-124.

Ryding, S. O. \& W. Rast (eds.). 1989. The control of eutrophication of lake and reservoirs. Man and the Biosphere Series. $314 \mathrm{p}$.

Samuel, S. Adjie \& A. D. Utomo. 1991. Aspek biologi udang galah ( $M$. rosenbergii) di Sungai Lempuing Sumatera Selatan. Buletin Penelitian Perikanan Darat Bogor. 10 (2): 32-39.
Sarnita, A. 1972. Laporan singkat hasil survey perikanan Waduk Darma dan Situ Patok, Jawa Barat. Laporan Stasiun Penelitian Perikanan Jatiluhur. 8 hal. (Tidak dipublikasikan).

Satria, H. 2001. Studi habitat udang galah (Macrobrachium rosenbegii) dalam rangka pengkayaan stok di perairan Waduk Darma. Laporan Proyek Balai Penelitian Perikanan Air Tawar Sukamandi. 21 p.

Sokal, R. R. \& F. J. Rohlf. 1995. Biometry: the principles practice of statistics in biological research. W. H. Freeman and Company. 877 p.

Spotts, D. 2001. Introducing Macrobrachium rosenbergii. www.miami-aquaculture.com. 5 p. 14 September 2001.

Tjahjo, D. W. T. 2000. Aspek biolimnologi perairan Waduk Darma, Jawa Barat. Jurnal Penelitian Perikanan Indonesia. 6(3-4): 10-15.

Tjahjo, D .W. H., S. Nuroniah, \& S. E Purnamaningtyas. 2001. Evaluasi biolimnologi dan relung ekologi komunitas ikan untuk menentukan jenis ikan yang ditebar di Waduk Darma. Jurnal Penelitian Perikanan Indonesia. 7(1): 10-24 p.

Tjahjo, D. W. H., E. S. Kartamihardja, \& S. E. Purnamaningtyas. 2004. Evaluasi penebaran udang galah (macrobrachium rosenbergii) di Waduk Darma, Jawa Barat: kualitas air dan potensi sumber daya perikanan. Jurnal Penelitian Perikanan Indonesia, (dalam proses publikasi).

Tidwell, J. H., S. Coyle, R. M. Durborow, S. Dasgupta, W. A. Wuris, F. Wynne, L. A. Bright, \& A. Van Arnum. 2002. Kentucky State University prawn production manual: The Maylasian freshwater prawn has received the most attention from farmers because of its large size. Kentucky State University, Aquaculture Program. 44 p.

Widana, K. \& P. Martosubroto. 1986. Pengelolaan perikanan perairan umum dan masalahnya. p. 4355. Prosiding Seminar Perikanan Perairan Umum Jakarta 1 September 1986. Badan Penelitian dan Pengembangan Pertanian, Pusat Penelitian dan Pengembangan Perikanan.

Wynne, F. 2002. Kentucky State University prawn production manual: The Maylasian freshwater prawn has received the most attention from farmers because of its large size. Kentucky State University, Aquaculture Program. $44 \mathrm{p}$ 
Lampiran 1. Peta Waduk Darma

Appendix 1. The map of Darma Reservoir

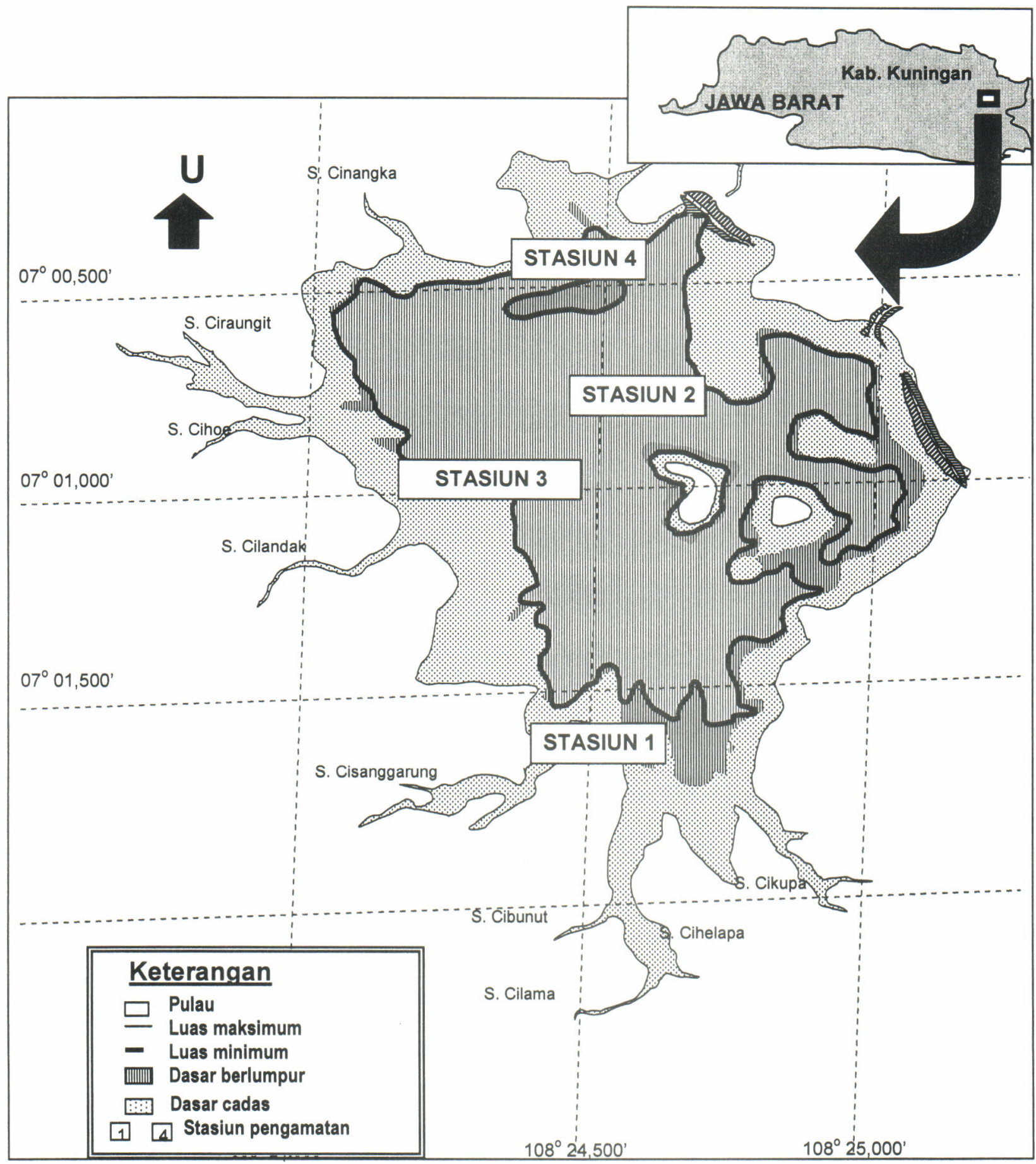

